\title{
ANALYSIS OF THE LONG-TERM IMPACTS AND BENEFITS OF GRAND TETON NATIONAL PARK ON THE ECONOMY \\ OF TETON COUNTY, WYOMING
}

\author{
Shelby Gerking \\ John Merrifield \\ Institute for Policy Research \\ University of Wyoming
}

\section{Objectives}

The research underway has two primary objectives. The first of these is to document the impact of Grand Teton National Park (GTNP) on the demographic characteristics and economy of Teton County. Such documentation will provide a basis to address specific local concerns expressed about some GTNP management policies.

The second major objective is to improve the National Park Service's (NPS) ability to predict the economic impact of management policies being considered, thus enabling the NPS to make adjustments in policies where appropriate. The capability to make such predictions will reduce controversy and conflict, and thereby improve the decision-making environment. It will also enable the NPS to update many of the findings of the research, thus maintaining the value of the study well beyond the piriod immediately following its completion.

\section{Methods}

The detailed discussion of the research methodology included in the proposal will not be repeated here. Only the central themes of the methodology as they relate to the objectives stated above will be summarized.

The first objective is being addressed in part by a number of trend analyses. To address some existing local concerns, trends in a variety of local tax sources have been plotted. Sales tax data are used as an indicator of retail sales activity. Census data are to be the basis for the demographic analyses. Aggregate population growth, changes in age-sex distribution, and migration will be analyzed. A recent campground survey and the Greater Yellowstone Transportation Study provided some recreational activity data.

Both objectives are addressed by an economic base model of Teton County. The model will be completed by the incorporation of recently released 1980 Census data before the end of December. Detailed employment and income breakdowns were generated from County Business Patterns

$$
-64-
$$


(published annually by the Census Bureau) and Bureau of Economic Analysis data. Important adjustments for the data's seasonal bias were accomplished with the aid of personal interviews with Teton County citizens and monthly sales tax data. Employment and income multipliers have been calculated from those breakdowns, and the stability of those multipliers has been studied. NPS employment, payroll, visitation data, and a survey of visitors' average length of stay and expenditures, together with the multipliers, provide an estimate of gross GTNP-related population.

The distinction between gross and net GTNP impact is a very important one. If GTNP had not been created in 1929 and expanded in 1950, the area now managed by the NPS would probably be a mixture of national forest, private, and wilderness area land. On the basis of that hypothesis, an area comparable to that hypothetical GTNP-less Teton County was selected as a basis for net impact calculations. Park County, Montana, was the area selected. Gardiner and Cooke City (located in Park County) are Yellowstone National Park (YNP), gateway communities located at the northern and northeast entrances to YNP, respectively. Park County, Montana is similar to Teton County in terms of population, scenic beauty, and is a mixture of national forest, private land, and wilderness areas. Interviews with Park County Chamber of Commerce officials, and data provided by YNP and Gallatin National Forest officials, provided a basis for an estimation of Park County's visitors and their average length of stay. Contrasting Park County and Teton County visitation provided an estimate of net GTNP impact on Teton County.

\section{Results}

Preliminary analyses indicate that Teton County has increased its share of Wyoming's local tax revenues and retail sales faster than its share of the state's population. In other words, Teton County's per capita share of Wyoming's economy is growing. That is a somewhat amazing result in light of the extensive recent growth in Wyoming's economy through energy development. A comparison of Teton County to other Wyoming counties where energy developments have not been significant is not yet complete.

The economic base multipliers for income and employment are 1.46 and 1.49 respectively. The multipliers are based on 1978 data. Analysis of the years 1976-79 indicated that the multipliers are relatively stable and should remain so for the forseeable future. Teton County's population is not yet large enough to support new locally-provided services. Such services would increase the time a dollar remains in the county before leaving as payment for imports.

Visitation comparisons indicate that in a relatively good year, such as 1978, GTNP will receive about four million visitors, while only about one million people will visit Park County, Montana. Also, the average Teton County visitor stays about two days, while the average Park County visitor stays one day. 
While nearly all the data have been collected, most analyses will be completed between December 20 and January 15. A rough draft, ready for NPS review and comment, should be completed during February.

\section{Conclusions}

If one accepts the assumption that Park County, Montana is a reasonably true representation of a GTNP-less Teton County, the net impact of GTNP on Teton County's economy is very large in the positive direction. Most of the other data (not yet fully analyzed) appear to support such a conclusion as well.

\section{Literature Cited}

Premer, G. E., Lewis, E. P., Fletcher, R. R. and Taylor, D. T. 1979. Recreation and Tourism in the Teton County Economy. Agricultural Extension Service, Community Services Division, University of Wyoming.

Watts, Gary L. 1976. A Study of Campground Utilization in the Jackson Hole Area. Division of Business and Economic Research, University of Wyoming. 